\title{
MARKETING DOMINANT IN MODELS OF ENTREPRENEURIAL STRUCTURES INNOVATIVE POTENTIAL DEVELOPMENT FOR COMPETITIVE BUSINESS STRATEGY REALIZATION
}

\author{
VALENTYNA STADNYK ${ }^{1}$, GALINA KRASOVSKA ${ }^{2}$, YULIIA HOLOVCHUK ${ }^{3}$ \\ ${ }^{1}$ Khmelnytskyi National University \\ ORCID: https://orcid.org/0000-0002-2095-3517 \\ e-mail: stadnyk_v_v@ukr.net \\ ${ }^{2}$ Khmelnytskyi National University \\ ORCID: https://orcid.org/0000-0003-2589-5376 \\ e-mail: sokoliukg@gmail.com \\ ${ }^{3}$ Vinnytsia Institute of Trade and Economics of Kyiv National University of Trade and Economics \\ ORCID: https://orcid.org/0000-0002-4516-109X \\ e-mail: y.holovchuk@vtei.edu.ua
}

\begin{abstract}
The economic entities competitiveness is determined by their ability to create consumer values. Consumer markets dynamic requires mobility in the competitive strategic choice that means it requires those innovative potential components predominant development that provide enterprises with such mobility. The paper aims to form theoretical bases of business structures innovative potential development to improve their dynamic characteristics and increase the ability to implement competitive business strategies. Innovations theory, competitive advantages resource theory, concepts of strategic management, network structures and marketing relationship have been chosen as the research theoretical basis. Based on the machine-building products dynamic and export structure analysis and the Ukraine industrial enterprises innovative activity results, the assumption that their innovative potential do not correspond to the competitive strategies objectives has been suggested. It has been substantiated that the innovative potential development management should be considered in terms of improving the enterprises adaptive and proactive flexibility and that is provided by the marketing function. Based on the above the model of enterprise competitive business strategy selection considering the possibility of building up innovative capacities through the strategic partnerships development has been designed. The motivational environment impact on the partnerships value has been formalized and the task of marketing relationship in this process have been identified. The research results can be useful for the dynamic characteristics and economic systems competitiveness development.
\end{abstract}

Keywords: industry, machine-building, adaptive flexibility, proactive flexibility, innovation strategy, motivational environment, marketing relationship

DOI: $10.31891 / \mathrm{mdes} / 2021-1-4$

\section{INTRODUCTION}

In today's economic environment, the sustainable growth and socio-economic systems development are possible only due to their ability to accumulate new knowledge and transform it into new products (services) that have consumer value. This ability is especially necessary in the context of the global economic crisis, which is beginning now. The COVID-19 pandemic has become a trigger for this crisis, whose rapid deployment casts doubts on the globalization benefits and resuming discussions about its scale feasibility. And not only in the millions of people life-saving light, but also in the many businesses types inevitable economic losses context, this can disrupt the national economies established structures and threaten their economic security. This crisis pandemic nature has worsened consumer demand in many market segments. In addition, the quarantine restrictions that are taken by the most countries governments for slowing the COVID-19 proliferation pace have led to the numerous logistics chains disruption and this greatly complicated many business processes.

As a result, a significant decrease in industrial production is expected (depending on industry specialization). This will lead to the major job losses - especially on machine-building enterprises that manufacture products for production systems reproduction of other industries economic entities. Under crisis circumstances, such reproduction is usually complicated - both due to investment resources lack and because of consumer markets future state uncertainty. The global financial and economic crisis effects confirmed this in 2008-2009 - the largest decline was in machine-building industry. In Ukraine in 2009 it reached more than $45 \%$ of the previous year; in industry the total decrease was about $22 \%$ [1].

However, the sophisticated technical products development is an important component of maintaining the economic security proper level and national economies viability. After all, the technologically complicated production systems number reducing in the country causes the highly skilled work skills loss and does not create motivational preferences for intellectual work in the engineering and design fields. This adversely affects the whole country human development quality and pace. As a result, businesses are increasingly unable to produce high value-added products and are focused mainly on natural resources intensive and predatory use, this forms the country's export structure. 
The presence of such disparities in the modern Ukraine's economy is extremely urgent to overcome them for enhancing the country's ability to withstand the threats of global challenges and maintain an economic security proper level. One way to solve it can be national economy machine-building sector development positive dynamic restoration. But most machine-building enterprises production systems current state requires their significant technical and technological updating, as well as organizational changes: in the business processes structure, in the management functions relations, in the personnel qualification structure, etc. These tasks innovative nature and their interconnectedness requires due attention to the enterprises innovative potential development.

The paper aims to form theoretical bases of business structures innovative potential development to improve their dynamic characteristics and increase the ability to implement competitive business strategies.

\section{THEORETIGAL BASIS}

Market competition needs innovations, so each business entity must create its own mechanisms and organizational structures to transform new knowledge into competitive advantages. This approach axiomatic nature to ensuring the market participants viability is confirmed by the practice of developed countries management and the innovative factors dominance in the productivity factors set is seen in modern economic growth concepts. Their implementation management aspects are best reflected in the works of B. Wernerfelt (Resource-Based View of the Firm, 1984) [2], D.Teece, G.Pisano, \& F.Shuen (Dynamic capabilites and strategic management, 1995) [3], A. Slywotzky (Value Migration: How to Think Several Moves Ahead of the Competition, 1995) [4], A.Brandenburger \& B.Nalebaff (Co-opetition, 1996) [5], G.Hamel \& C.Prahalad (Competing for the Future, 1997) [6], W.Chan \& R.Mauborgne (Blue Ocean Strategy, 2004) [7], J.Moore (Business ecosystems, 2006) [8].

These and other scientific works conceptually outline different methodological approaches to the market participants (enterprises) competitive advantages formation. However, the main sources of competitive advantage remain innovations only the approaches to the conditions creating for their implementation by business entities change.

Let's leave out of this work the institutional factors that shape the economic entities motivational preferences. In different countries, they have their key characteristics that determine both the economic development overall dynamic and the individual market players' dynamic abilities (G.Hodgson) [9]. Some aspects of the institutional environment impact on the Ukraine's economy competitiveness and development we have investigated in the previous work [10]. However, the research concerned the improvement of the institutional environment at the macro level - above all through reasonable preferences in the field of taxation and lending for production systems technological renewal, as well as through the collective action institutions development (regional innovation infrastructure).

However, the motivational environment formed by institutions that operate outside the direct influence of the economic entities management, forms only their economic behavior vectors. Internal organizational and economic circumstances are needed to obtain concrete results. For innovations, such conditions are provided by the innovative potential development.

For the first time, the term "innovative potential" was introduced by C. Freeman [11], he interpreted it as a factor that ensures the growth of the economic system through innovations. He applied it in the context of the national innovations system characteristics, which is integration result of structures' heterogeneous goals and objectives engaged in the scientific knowledge and technologies production and commercial realization within national borders. Today, scientific research on the economic systems innovative potential management is conducted at the micro level, with emphasis on the innovations creation and practical applicability in particular business. Among the most interesting modern researches in the field of innovations are the works of S.Anthony, M.Eyring \& L.Gibson [12], J.Tidd, J.Bessant \& K.Pavitt [13].

Such studies have become especially widespread in the post-Soviet space - given the actual removal of the state from the function of scientific activity managing and its transfer to commercial rails. Now the problem investigation for enterprises innovative potential development is conducted by many scientists. Despite the considerable scientific achievements in this field, discussions continue regarding its structure, elemental composition, development conditions, realization degree, optimization modeling possibilities and some other aspects, including those that reflect the economic entities industry specificity.

Most often, researchers base the foundation for structuring on the individual components functional purpose (B.Annayev [14]); (I.Sydorchuk [15]); (V.Gurochkina [16]) or by linking them to an enterprise resource base (T.Zubko and V.Andreeva [17]). However, in the studies of these and many other 
scientists, the enterprise's innovative potential task creation is limited by an abstract objective function, which is described as «the ability to create and commercialize new products (services)».

In the innovative potential development managing tasks context, many scientists propose to focus on the evaluating its condition procedure, using for this purpose the quantitative and qualitative methods to evaluate the individual components use effectiveness or their integral evaluation. For example, this approach is followed by I.Sydorchuk [15], Sh.Valitov \& A.Khakimov [18]. Their recommendations differ in the degree of innovative potential components details and indicators for their evaluation, as well as the purpose.

In particular, I.Rodionova [19] set out to develop recommendations for enhancing the light industry enterprises innovative potential; B.Annayev [14], Sh.Valitov \& A.Khakimov [18], M.Chorna, G.Nord, L.Bezghinova, I.Melushova \& A.Diadin [20] - in the context of mechanism for managing the innovative potential development, without taking into account industry specifics. However, the calculations of these and other scientists usually do not contain the criteria of compliance with the indicators to a certain innovative potential condition and do not take into account the specific competitive strategies for the enterprise in its activity industry specifics context. In our opinion, it is necessary to differentiate the innovative potential structural elements by their role in ensuring the innovative process effectiveness, taking into account the activity specifics in the target markets. Then, depending on the individual components importance in maximizing consumer value for the target consumer groups, it will be possible to develop a program for the enterprise intellectual potential development.

One of the optimization modeling option of the enterprise innovative potential structure according to this approach was made by O.Zamazii, V.Stadnyk, G.Sokoliuk \& N.Prylepa [21]. However, the research was conducted only in the particular products context. But machine-building enterprises usually produce products wide range the design and commercialization of which differ in many aspects. And it takes great efforts to form the innovative potential technological component for adding the latest flexible and resourcesaving technologies to the innovative process. At the same time, the technically complex innovations commercialization has its own specificity. This is emphasized in research of M.Treacy \& F.Wiersema [22], V.Khachatrian [23], I.Tatomyr [24]. It can also take the in-company training form to acquire employees new competencies in the marketing and communications research field and the entrepreneurship development [25].

The marketing function is gaining the most weight in the product development strategies for new markets context - especially when entering other countries markets. This is emphasized in research of M.Bianchi, A. Benedetto, S.Franzo \& F.Frattini [26]. For the Ukrainian machine- building enterprises, this task is extremely important - since in the developed countries markets there is still a lack of confidence in the Ukrainian machine-builders products quality characteristics, which reduces its competitiveness. Overcoming this distrust is possible through the joint efforts of product developers and those who determine its value to target consumer groups, taking into account new markets standards and requirements. To the development of such functions in the machine-building enterprises innovative potential structure should be given the highest attention.

In general, with the existing differences in the scientists views regarding the use of certain scientific-methodological or even methodological approaches for managing the innovative potential development, the researchers' positions coincide in one - the innovative potential is the enterprise management purposeful efforts result to attract and accumulate the resources that form the employees ability to perform new tasks and create new products (services) that have consumer value.

In its structure, the innovative potential must be an elements set (based on the enterprise industry specific nature) and the links between them, which will provide the enterprise with flexibility and ability to respond quickly to dynamic market changes. At the same time, modern production of technically complex products is characterized by industrial specialization high level, which means that there is a significant resource and technological dependence of the participants in the value chain. Therefore, in order to formulate and implement competitive strategies in machine-building sphere, it is advisable to increase the technological chains innovative potential, not of individual enterprises, but of all participants in organizationally affiliated relationships.

This is emphasized in research of P. Hrihoruk \& N. Khrushch [27], R.Taddeo, A. Simboli, G. Ioppolo, \& A. Morgante [28]. In our view, achievement for such flexibility is the innovative potential characteristic key, according to which the level should be assessed and the tasks of its managing development determined. Flexibility should be proactive and maximally effective, ensuring the innovations creation and implementation within a timeframe sufficient to shape and sustain the enterprise competitive advantage in the management selected strategic area. In order to do this, innovative changes 
should be coordinated in all value chain parts that requires adequate partnerships for formulating business strategies that are agreed upon on the key parameters of products competitiveness.

However, the network interaction practice widespread, in most economic activity areas, indicates that partnership is increasingly recognized as a successful alternative to market competition for business entities (N. Roig-Tierno, D. Ribeiro-Soriano \& F. Mas-Verdú [29]); (M. Dodgson [30]). Such partnership organizational development is carried out on the competence and resource complementarity principles for maximizing the objective function (V. Stadnyk, P. Izhevskiy, O. Zamazii, A. Goncharuk \& O. Melnichuk [10]). Through the partnerships development, it is possible to enhance mutually the innovative potential of all participants in the partnership, expanding the competitive business strategies choice ability.

And this brings the problem for innovative potential development of the enterprise beyond its limits and can be considered in the strategic goals context on larger-scale socio-economic systems. The importance and relevance of these issues to ensure the national economy sustainable development in the global economic crisis context has determined the purpose of this study.

\section{STUDY RESULTS}

For the machine-building industry in Ukraine, the competitiveness problem is exacerbated every year. And there is an objective explanation - the military-political and economic confrontation between Ukraine and the Russian Federation has caused the loss of machine-building on old-line markets. At the same time, such economic dynamics prolonged deterioration in the machine-building industry in Ukraine is caused by the fact that in the other countries markets these products for the most part are not competitive enough.

International competitiveness is reflected not so much by the potential for the high-tech products unique models creation (for example, in the aircraft industry) as by its export volumes. Unfortunately, since 2012, the export of machine-building products in Ukraine has a negative trend, as indicated by the statistical data for 2011-2020 in Table 1 (State Statistics Service of Ukraine [31]).

Table 1

Ukraine machine-building products main export indicators dynamics *

\begin{tabular}{|c|c|c|c|c|c|c|c|c|c|c|}
\hline \multirow{2}{*}{ Product groups } & \multicolumn{10}{|c|}{ Indicators value by years } \\
\hline & 2011 & 2012 & 2013 & 2014 & 2015 & 2016 & 2017 & 2018 & 2019 & 2020 \\
\hline \multicolumn{11}{|c|}{ Machine-building products export, billion USD } \\
\hline Total, & 11,70 & 12,94 & 10,38 & 7,36 & 4,78 & 4,35 & 5,05 & 5,47 & 5,52 & 5,41 \\
\hline $\begin{array}{l}\text { of them }{ }^{* *}: \\
-1 \text { product group }\end{array}$ & 6,63 & 6,87 & 6,82 & 5,66 & 3,94 & 3,64 & 4,27 & 4,65 & 4,46 & 4,49 \\
\hline - 2 product group & 4,79 & 5,78 & 3,27 & 1,47 & 0,68 & 0,56 & 0,63 & 0,67 & 0,88 & 0,76 \\
\hline $2 \mathrm{a}$ & 0,32 & 0,92 & 0,31 & 0,25 & 0,19 & 0,08 & 0,03 & 0,06 & 0,07 & 0,08 \\
\hline - 3 product group & 0,28 & 0,29 & 0,29 & 0,23 & 0,16 & 0,15 & 0,15 & 0,15 & 0,18 & 0,16 \\
\hline \multicolumn{11}{|c|}{ Machine-building products export structure by product groups, $\%$} \\
\hline Total, & 100,00 & 100,00 & 100,00 & 100,00 & 100,00 & 100,00 & 100,00 & 100,00 & 100,00 & 100,00 \\
\hline $\begin{array}{l}\text { of them**: } \\
-1 \text { product group }\end{array}$ & 56,67 & 53,09 & 65,70 & 76,90 & 82,43 & 83,68 & 84,55 & 85,01 & 80,80 & 82,99 \\
\hline - 2 product group & 40,94 & 44,67 & 31,50 & 19,97 & 14,23 & 12,87 & 12,48 & 12,25 & 15,94 & 14,05 \\
\hline $2 \mathrm{a}$ & 2,74 & 7,11 & 2,99 & 3,40 & 3,97 & 1,84 & 0,59 & 1,09 & 1,27 & 1,48 \\
\hline - 3 product group & 2,39 & 2,24 & 2,79 & 3,13 & 3,35 & 3,45 & 2,97 & 2,74 & 3,26 & 2,96 \\
\hline \multicolumn{11}{|c|}{ Change in export by product groups compared to the previous year, $\%$} \\
\hline Total, & - & 110,60 & 80,22 & 70,91 & 64,95 & 91,00 & 116,09 & 108,32 & 100,91 & 98,01 \\
\hline $\begin{array}{l}\text { of them }{ }^{* *} \text { : } \\
\text { - } 1 \text { product group }\end{array}$ & - & 103,62 & 99,27 & 82,99 & 69,61 & 92,39 & 112,6 & 108,8 & 95,9 & 100,67 \\
\hline - 2 product group & - & 120,67 & 56,57 & 44,95 & 46,26 & 82,35 & 36,8 & 106,9 & 131,8 & 86,36 \\
\hline-3 product group & - & 103,57 & 100,00 & 79,31 & 69,57 & 93,75 & 104,0 & 98,0 & 122,0 & 88,89 \\
\hline
\end{tabular}

* 2014-2020 - without taking into account the temporarily occupied territories of the Autonomous Republic of Crimea,

Sevastopol and parts of Donetsk and Luhansk regions

** Notation keys

1 product group - machines, equipment and mechanisms; electrical equipment

2 product group - surface, aircraft and floating transport assets; $2 a$-including aircraft

3 product group - optical instruments and apparatus, photographic

In addition, our calculations of the machine-building export structure by product groups types show that high-tech equipment (aircraft, devices and apparatus) is very small proportion and its dynamic extremely poor. Thus, in 2013, \$310.0 million worth of goods were exported from the aircraft group. In 2017, this amount decreased by an order of magnitude - to $\$ 29.03$ million USA. In the next three years, exports under this item doubled, but made up only $1.48 \%$ of Ukraine's total exports. Considering that 
Ukraine is able to produce products at the best world models level in aviation industry, the export results could be much better. This indicates insufficient efforts by product manufacturers to promote it in the global market.

However, there are also problems in the creating new and competitive designs field in Ukraine. This is indicated by the data on the innovations brought to the market (table 2 [32]. Among them, the new equipment fraction ranges about 20-35\%. And the smallest of them (as well as the number of new samples) were relatively prosperous in 2012-2013. The new technological processes number introduced into industrial production in those years was quite a bit too.

Table 2

Dynamics of the industrial enterprises innovation activity results in Ukraine*

Compiled based on the data from SSSU (2021)

\begin{tabular}{|l|c|c|c|c|c|c|c|c|c|}
\hline \multicolumn{1}{|c|}{ Indicators } & \multicolumn{10}{c|}{ Indicators by years } \\
\cline { 2 - 11 } & $\mathbf{2 0 1 1}$ & $\mathbf{2 0 1 2}$ & $\mathbf{2 0 1 3}$ & $\mathbf{2 0 1 4}$ & $\mathbf{2 0 1 5}$ & $\mathbf{2 0 1 6}$ & $\mathbf{2 0 1 7}$ & $\mathbf{2 0 1 8}$ & $\mathbf{2 0 1 9}$ \\
\hline New technological processes were introduced, units & 2510 & 2188 & 1576 & 1743 & 1217 & 3489 & 1831 & 2002 & 2318 \\
\hline Introduced new types of products, titles & 3238 & 3403 & 3138 & 3661 & 3136 & 4139 & 2387 & 3843 & 2148 \\
\hline Equipment new types among these & 809 & 769 & 657 & 1314 & 966 & 1305 & 751 & 920 & 760 \\
\hline $\begin{array}{l}\text { The new technology samples share in the product } \\
\text { innovations total number }\end{array}$ & 25,8 & 19,3 & 20,8 & 35,9 & 30,8 & 31,5 & 31,5 & 23,9 & 35,4 \\
\hline
\end{tabular}

* 2014-2018 - without taking into account the temporarily occupied territories of the Autonomous Republic of Crimea, Sevastopol and parts of Donetsk and Luhansk regions

The most productive in terms of innovation performance in the Ukrainian industry was 2016. That year almost three times more than the previous year new technological processes were introduced and almost $40 \%$ more against the previous year new technology models were introduced. It can be assumed that a strong impetus for the innovative activity growth in Ukrainian industrial enterprises was the urgent need to change markets - after the old ones loss. And this has yielded positive results, embodied in product and process innovations.

However, the ultimate goal of an enterprise's innovative activity is not so much the new products or technologies number brought to the market (if the innovations were, their scale or efficiency irrespective, the enterprise refers to the innovative-active ones), as the economic results that the enterprise will receive from it. The greater the innovations consumer value and the greater their market potential, the more they affect the overall economic dynamics. It is reasonable to assume that the total sales volume of industrial enterprises due to their innovative activity should increase.

Relevant statistics have been used to determine the existence/absence of such linkage in the national industrial sector. Figure 1, which is based on data [32], correlates Ukraine industrial enterprises innovative activity with the results in the dynamics of recent years. As can be seen from Figure 1, this connection is to some extent confirmed by the next: after the burst of enterprises innovative activity in 2016 (16.6\% of enterprises engaged in innovation) in the next year, the industrial products sales volume increased for $20 \%$. However, a broader retrospect shows that for many years the innovative activity growth does not contribute to the increase in the share of innovative products. On the contrary, in the total volume of products sales by industrial enterprises, this fraction is steadily decreasing - from $3.8 \%$ in 2011 to $0.8 \%$ in 2018. Moreover, in 2017 (by the largest industrial products sales volume) this fraction was even lower only $0.7 \%$. This may indicate that the enterprises innovative activity efficiency is not sufficiently high. And also about that there is no correlation between the goals of the enterprises and the structure of their innovative potential. After all, the opportunities laid down in the latter have to be realized in order to accomplish the tasks for which these opportunities were formed.

For machine-building enterprises such task is the flexibility necessary level achievement in responding to the scientific and technological progress trends that affect consumer demand. First, it translates into their ability to create competitive and marketable products. At the same time, it is important to ensure a proper return on the implementation of innovation - sufficient to enable management to prioritize innovative factors when choosing a competitive strategy, thereby generating appropriate innovative potential.

It is the innovative potential that determines the enterprise dynamic characteristics - its adaptive and proactive flexibility in the field of creating consumer values and their commercialization. In our view, adaptive flexibility is provided by the resource-functional component of innovative activity, and proactive is provided by motivational one. 


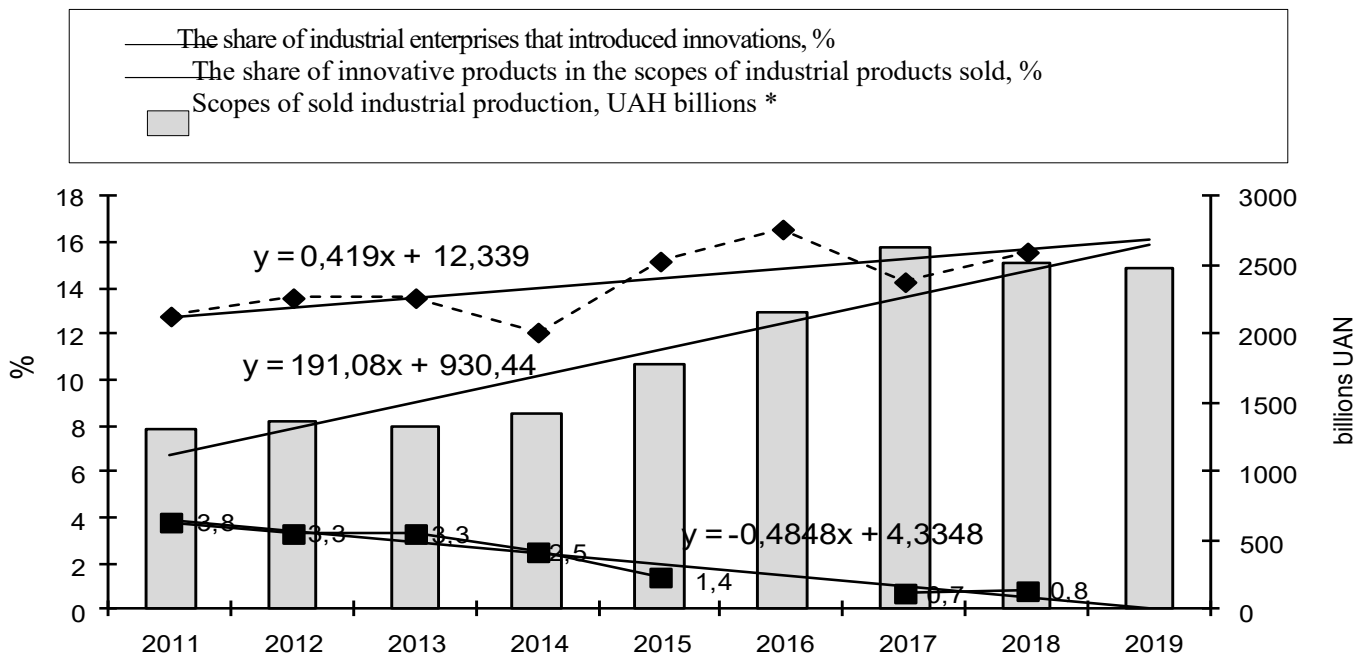

Figure 1. Comparative dynamics of innovative activity of Ukraine industrial enterprises and its results Source: Calculated and built based on the data from SSSU (2020)

In the context of this statement, it is advisable to consider the enterprise innovative potential (as well as the larger socio-economic systems) in the light of two interrelated components:

a) resource-functional - in the form of a resources set that are functionally necessary and sufficient to carry out a successful innovative process in line with the chosen strategy of activity;

b) motivational - in the form of mutually beneficial for the participants organizational and economic cooperation conditions, that create a motivational (and therefore competent) environment for effective innovative activity.

These components interaction provides the adaptive and proactive flexibility of economic entities and their innovative activity, which is embodied in product or process innovations that underpin the competitive advantages and competitive business strategies (Figure 2).

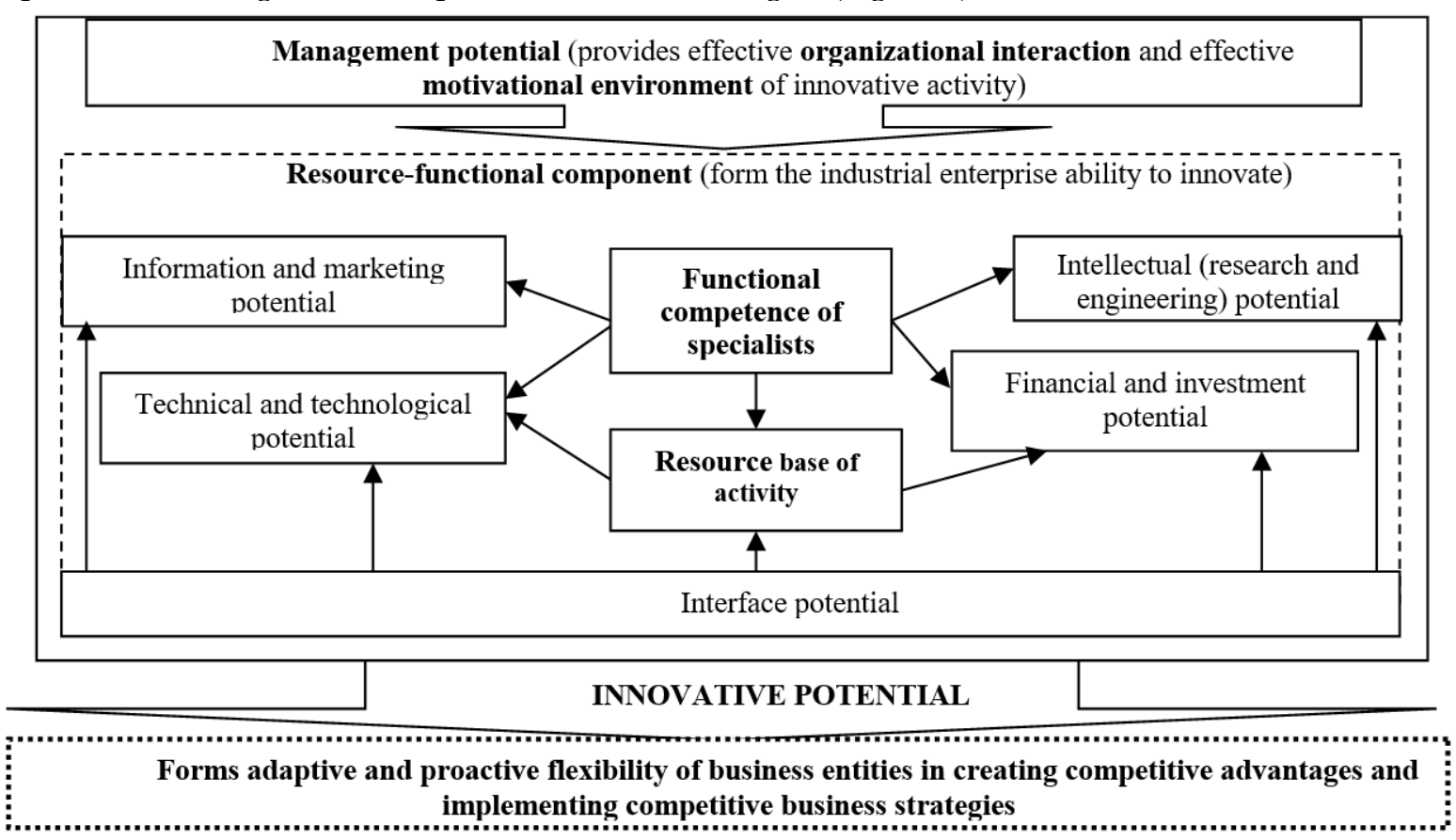

Figure 2. Structural and functional model of industrial enterprise innovative potential

Source: Developed by authors

Research and engineering potentials are the core of an enterprise's innovative potential, which determines its ability to innovate transformations level. Embodied in the intellectual capabilities and abilities of employees, they determine the ability of the company to generate and perceive ideas and the implementation of creative thinking relevant to the current level of development of science and technology. 
At the same time, a modern enterprise innovative potential structure should includes: organizational and managerial component (leadership technologies and teambuilding, which ensure the effective use of intelligence to create and realize new knowledge), information and marketing component (marketing technologies of working with information on market processes), technical and technological component (technical means integrated into the technological process necessary for new products and processes creation), financial and investment component (financial resources availability and tools for innovative process investment support), and also interface component that provides innovative process involving the owners of unique resources beyond the existing partnership.

The innovative potential marketing component plays a special role in shaping the flexibility of a business entity. Above all, it should provide the market qualified analysis and identify consumer needs trends in strategic management areas. The results of such analysis serve as a basis for determining the directions of formation the enterprise competitive advantages in the ways and means of meeting these needs, in particular, through innovative changes.

At the same time, marketing approaches are appropriate to use for evaluation:

- the potential utility of inventions and discoveries that have emerged in the innovation market and can be realized - to determine the feasibility of involving them in the practice of an entity activity;

- the economic entities partnership forms that can be participants in the production technological chain - to plan the mutually agreed changes in the resources and business processes structure composition;

- $\quad$ changes in legislation that may form certain sectoral or regional preferences for the relevant strategic period - to assess their impact on the competitive environment development and to identify new activity areas.

Considering that innovative potential is formed for innovative tasks realization which are form the enterprise competitive business strategy basis, and also that competitive strategies are chosen by management for each business context that is deployed in strategic perspective, it can be argued that there is interdependence processes of innovative potential formation and harnessing. On the one hand, its development should take place in line with the selected business strategies, and on the other hand, business strategies should be chosen taking into account the capacity of certain structural components of the enterprise's innovative potential to generate sustainable competitive advantages. That brings the forecast marketing function to the forefront. So, based on its market trends, options for the other innovative potential components development should be considered. And in the context of forward-looking business strategies for retaining / strengthening competitive advantage.

Any competitive business strategy should be based on innovation, which gives reason to speak about its direct connection with innovative strategies. And it can be argued that wrong choice of strategic goals achievement methods and technologies indeed largely a consequence of the enterprise innovative potential structure imbalance and absence (or insufficient level of development) of its components that are necessary for the implementation of key innovative goals. To avoid this it is important to see the connection between the innovative potential components and the enterprise strategic goals, which are determined by its innovative and business strategies (table 3).

Machine-building enterprises often are partners in the technology chain, and their strategy depends on what strategy is implemented by the dominant partner in the chain (often the one that marketed finished product). Subsidiaries do not attempt to change their products on their own because they are closely linked to the requirements of a leading enterprise. At the same time, they can initiate such changes if their development can significantly improve the quality for the final product. The key role in determining the direction of enhancing the innovative potential of participants in such a partnership should be played by the producer of the final products - in fact it is in direct contact with the market and develops the concept of new products in line with the trends of scientific and technological progress.

The solution to these problems belongs to the sphere of marketing and requires adequate information and analytical support. It is advisable to justify and make appropriate decisions by actively interacting with existing/potential partners, involving them in mutually agreed organizational or technological changes. This is shown schematically in Fig. 3.

Guided by the author's determination of the enterprise innovative potential in the part related to ensuring its dynamic characteristics (that is the ability to changes under the influence of new environmental challenges for the competitive strategies implementation), we consider it necessary to emphasize once again that the motivational environment conducive for innovative activity should be created for this. In addition, its most sensitive components must be dynamic, this means to be promptly adjusted according to innovative tasks under the chosen business strategy context. 


\section{Connection of machine-building enterprise strategies with its ability to generate competitive} advantages at the expense of the innovative potential structural components

\begin{tabular}{|c|c|c|}
\hline $\begin{array}{l}\text { Method of competitive advantages } \\
\text { generating }\end{array}$ & Key competencies for competitive advantages & $\begin{array}{l}\text { A key structural and functional } \\
\text { innovative potential components }\end{array}$ \\
\hline \multicolumn{3}{|c|}{ Offensive strategy (growth) } \\
\hline $\begin{array}{l}\text { Market launch of a new product with } \\
\text { high consumer value for a mass } \\
\text { audience }\end{array}$ & $\begin{array}{l}\text { Ability to create new products brand } \\
\text { (breakthrough innovations) }\end{array}$ & $\begin{array}{l}\text { Research and engineering; } \\
\text { technological; marketing and } \\
\text { information; financial (investment) } \\
\text { potentials }\end{array}$ \\
\hline \multicolumn{3}{|c|}{ Niche strategy (limited growth) } \\
\hline $\begin{array}{l}\text { Markets monitoring to identify new } \\
\text { needs and create product innovations } \\
\text { with consumer value for market niches } \\
\text { identification }\end{array}$ & $\begin{array}{l}\text { Ability to highlight the consumers target } \\
\text { groups specific needs and to develop a way of } \\
\text { satisfying them }\end{array}$ & $\begin{array}{l}\text { Marketing information and } \\
\text { engineering potentials }\end{array}$ \\
\hline \multicolumn{3}{|c|}{ Protective strategy (limited growth) } \\
\hline $\begin{array}{l}\text { Product development and process } \\
\text { improvement }\end{array}$ & Ability to develop products and processes & $\begin{array}{l}\text { Research and engineering potentials; } \\
\text { marketing and information potentials }\end{array}$ \\
\hline \multicolumn{3}{|c|}{ Imitation strategy (growth or limited growth) } \\
\hline $\begin{array}{l}\text { Rapid commercialization of consumer } \\
\text { value created by others }\end{array}$ & $\begin{array}{l}\text { Acquire a license or pirate copying of an } \\
\text { existing model, which has market acceptance }\end{array}$ & $\begin{array}{l}\text { Marketing and information, } \\
\text { technological, financial and } \\
\text { investment potentials }\end{array}$ \\
\hline \multicolumn{3}{|c|}{ Dependent strategy (in line with dominant partner strategy) } \\
\hline $\begin{array}{l}\text { Partnerships establishment with end- } \\
\text { product manufacturers to participate in } \\
\text { the technology chain }\end{array}$ & $\begin{array}{l}\text { The ability of the production system to } \\
\text { provide the required quality standards of } \\
\text { components for participation in the } \\
\text { technological chain }\end{array}$ & $\begin{array}{l}\text { Technological and interface } \\
\text { potentials }\end{array}$ \\
\hline
\end{tabular}

All people determine their motivational priorities, taking into account their ability to satisfy the most relevant needs at the decision-making moment. It is important to identify correctly the needs of those employees who may be initiators of the new, and therefore to differentiate them in relation to the predicted and actual results of innovative work. Thus, it is possible to ensure the rewards valence (not only purely material) under innovators motivational preferences context. It will create favorable conditions for active and effective innovative activity and achievement of the goals set in each strategic period. This also applies to the structural and functional development of the enterprise innovative potential - structural elements filling with new competences, taking into account the selected business strategies specifics.

It is important to prioritize correctly the internal incentive system parameters, by appropriately embedding the incentives to create and deliver innovations. Considering that the organizational interaction effectiveness (which, of course, has a decisive influence on the innovations effectiveness) is a reflection of the workforce members' motivational advantages, it can be argued that the formation and enhancement of the enterprise innovative potential largely depends on the management ability to provide relevant motivation base for the:

- attracting employees who are able to create innovative products and maintain their desire to use effectively their knowledge and enterprise resources to identify and realize innovative tasks;

- capital relations development and the systemic trust formation in the workforce to overcome the manifestations of opportunistic behavior on the part of those who will be involved in the implementing innovative changes process.

The motivational process driving forces should not be considered only in the participants economic interests context - the innovations motivational field is much broader and includes both material and intangible rewards. And quite often the innovation effectiveness depends not only on the professional and competent employees characteristics, but also on the relations system in the workforce. These relationships are formed in the process of its development and are manifested in management styles and methods, characteristics and values of organizational culture, which also serves as a motivational basis for organizational behavior. 


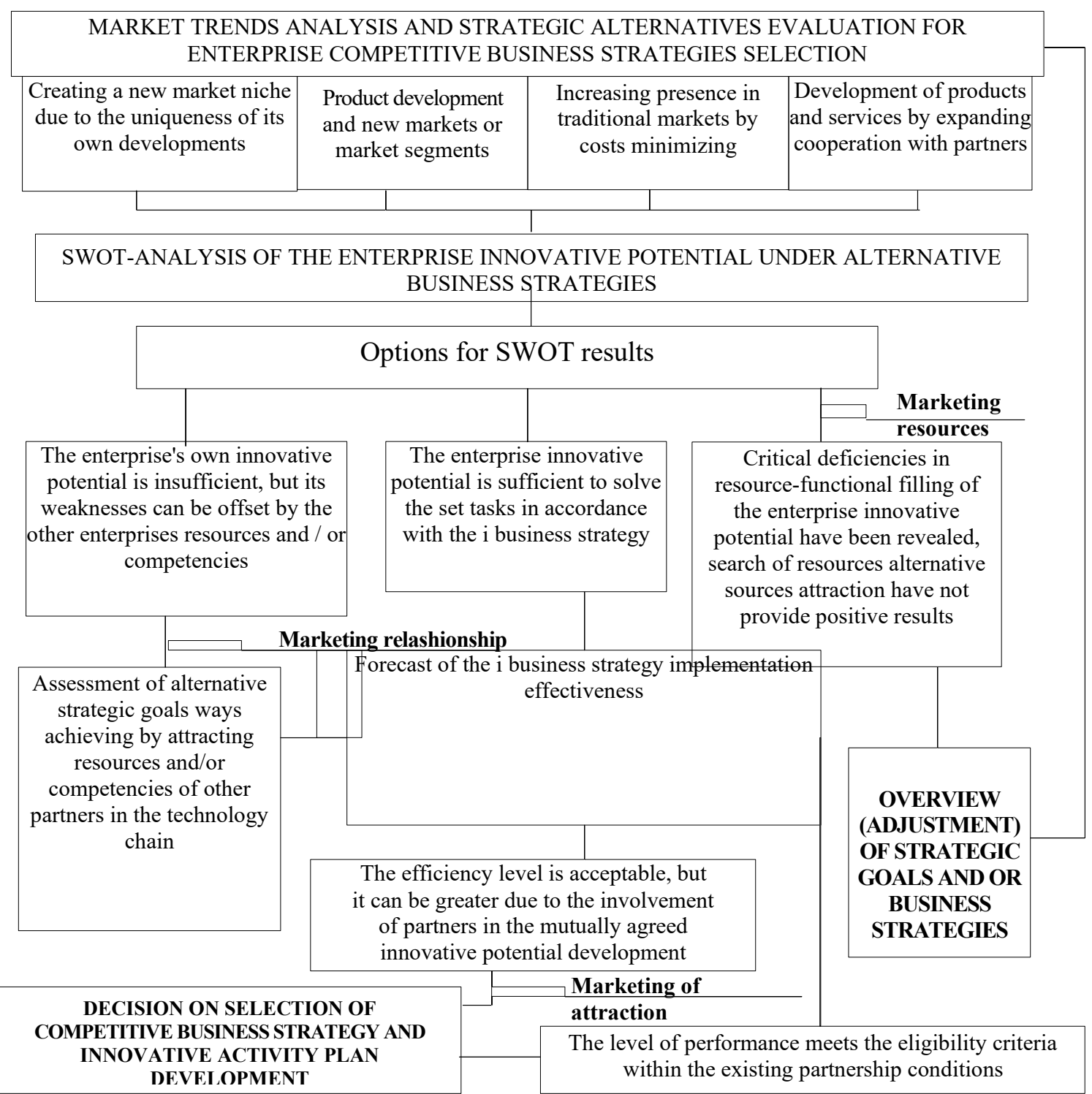

Figure 3. The model of the enterprise competitive business strategy selection considering the innovative potential increasing

Source: Developed by authors possibility on the basis of strategic partnership

Integrated business structures incentives-preferences in the field of innovation need should be formed not only in the organizational space of an individual enterprise, but also in the context of innovative development of all partners - if such a partnership is considered as strategic. To do this, we recommend to develope the motivational potential of engagement marketing, which is based on maintaining the partnerships value. Communication marketing interaction system will ensure the rapid exchange of information between the participants of the strategic partnership in relation with common goals and strategies, which may also be related to various aspects of innovative potential realizing.

It is extremely important for participants in integrated business structures to understand clearly the common benefits and the strategic partnership value. Therefore, the term «marketing interaction» should be interpreted in an active form - each participant should strive to improve the activities effectiveness in close interaction with partners. In such a partnership, business structures move from a predominantly adaptive market behavior scenario to a proactive one aimed at shaping new business segments in market - through the new knowledge production and new products creation, and technologies that develop social needs.

\section{CONCLUSION}

The problem of increasing the business structures competitiveness in Ukrainian industrial sector under the global economic crisis has been actualized. This problem is extremely acute for machine-building enterprises, which are losing their export opportunities every year. This has been confirmed by the machine-building products export performance analysis by major product groups in 2011-2020. Since 2012, 
the machine-building products export volume in Ukraine decreased more than twice, with the largest losses in export positions occurring in the product group, which covers the most high-tech products. Its share in the export structure decreased from $45 \%$ in 2012 to $14 \%$ in 2020, and its volumes decreased almost 11 times. It has been underlined that further degradation of the high value-added industry can become critical for renewable processes in industry and Ukraine will finally become a raw material supplement of developed countries.

Lost positions recovering is possible by enhancing the enterprises ability to create innovations that could form the competitive business strategies basis. We have been suggested that this requires the innovative capacity development in accordance with the ways to gain competitive advantage defined by the strategy. Based on the analysis of scientific perspectives on enterprises innovative potential management, it has been determined that they are lack of studies on the relationship between the innovative potential structure and competitive business strategies.

For factual confirmation of the stated assumption, we have conducted a study of the relationship between the industrial enterprises innovative activity dynamics in Ukraine in the period of 2011-2020 and its effectiveness. It has been found that even the enterprises innovative activity increase after 2014 did not provide a sustained growth in sales of industrial products, and therefore its competitiveness. Moreover, the innovative products share in 2019 was only $1.3 \%$ versus $3.8 \%$ in 2011. Taking into account the negative tendencies persistence and even their aggravation in recent years, we have concluded that the industrial enterprises innovative potential does not correspond to the tasks that they must solve in the competitive strategies selection and implementation processes.

The author's position has been stated that it is advisable to consider the innovative potential management development in terms of improving the dynamic characteristics that determine their adaptive and proactive flexibility. It has been argued that adaptive flexibility is provided by a resource component of innovative potential, and proactive flexibility by a motivational one. The essence of these components and their influence on the enterprise choice of the competitive business strategies type based on the productive innovations, has been characterized. The enterprises innovative strategies connection with its ability to form competitive advantages at the expense of innovative potential structural components has been determined and marketing key role in establishing the directions of business structures innovative potential development has been highlighted.

Considering the interconnectedness of industrial business structures in the value chain, the logical model of competitive business strategy selection based on business structures strategic partnership has been developed. In this model, the relationship marketing has been positioned and its target settings are identified in the work with the resource component of innovative potential (adaptive flexibility) and in improving the motivational bond of partnerships (proactive flexibility). It has been expressed the author's position on improving the motivational environment of innovative processes participants in strategic partnership through the monitoring partnerships value, which has been presented in a formalized form in the partners innovative potential context of increasing. The developed recommendations can be used to expand the directions and ways for marketing interaction of business structures (machine-building and other national economy industrial sectors ) within the framework of plans for building innovative strategic partnership opportunities for the competitive business strategies implementation.

\section{REFERENCES}

1. State Statistic Service of Ukraine. The Volume of industrial products sold by type of activity. Url: http://www.ukrstat.gov.ua/operativ/operativ2020 /pr/orppvd/orppvd_14-19_eu (accessed: 14.05.2021).

2. Wernerfelt B.A. Resource-Based View of the Firm. Strategic Management Journal. 1984.Vol.5. No 2. P.171-180.

3. Teece D.J. Pisano G., Shuen F. Dynamic capabilites and strategic management. Strategic Management Journal. 1997. Vol.18. No 7. P. 509-533. Doi.org/10.1002/(SICI)1097-0266(199708) 18:7<509::AID-SMJ882>3.0.CO;2-Z

4. Slywotzky A. J. Value Migration: How to Think Several Moves Ahead of the Competition. Harvard Business School Press, 1995. 336 p.

5. Brandenburger A.M., Nalebaff B. J. Co-opetition. New York, Crown Business. 1996. 304 p.

6. Hamel G., Prahalad, C.K. Competing for the Future. Harvard Business School Press. 1996. 358 p.

7. Chan W. K., Mauborgne, R. Blue Ocean Strategy. Harvard Business Review. 2004. 240 p.

8. Moore J. Business ecosystems and the view of the firm. The Antitrust Bulletin. 2006. Doi: 10.1177/0003603X0605100103.

9. Hodgson G.M. Economies and Institusion. A Manifesto for a Modern Institutional Economies. Cambridge Polity Press. $1988.346 \mathrm{p}$

10. Stadnyk V., Izhevskiy P., Zamazii O., Goncharuk A., Melnichuk O. Factors of enterprises' strategic selection of participation forms in integration formations. Problems and Perspectives in Management, 2018. Vol.16. No 2.P. 90-101. doi.org/10.21511/ppm.16(2).2018.09.

11. Freeman C. The National System of Innovationin Historical Perspective. Cambridge Journal of Economics. 1995. Vol.19.

No 1. 
12. Anthony S. D., Eyring M., Gibson L. Mapping Your Innovation Strategy [Online]. Harvard Business Review. 2006. May. Url: http:/ / hbr.org/2006/05/mapping-your-innovation-strategy/ar/1(accessed: 18.02.2021).

13. Tidd J., Bessant J., Pavitt K. Managing Innovation: Integrating technological, market and organizational change. 3-d Edition. Chichester, UK: John Wiley \& Sons LTD. 2005. 582 p.

14. Annayev B. Formation of innovative potential: opportunities of the enterprise and requirements of market. Economics. Management. Business. 2014. No 3. P.14-21. (in Ukrainian) Url: http://journals.dut.edu.ua/index.php/emb/issue/view/38 (accessed: 12.02.2021).

15. Sydorchuk I P. Essence, structure and features of evaluating the innovative potential of an industrial enterprise. Economic and region. 2014. No2(45). P.97-101. (in Ukrainian). Url.http://www.irbis-nbuv.gov.ua/cgibin/irbis_nbuv/cgiirbis_64.exe?econrig_2014_2_18 (accessed: 14.05.2021).

16. Gurochkina V. V. Innovation potential of the enterprise : the essence and protection system. Economics: time realities. Scientific journal. 2015. No5(21). P.51-57. (in Ukrainian).

17. Zubko T., Andreeva V. The meaning and methods of evaluation of innovative potential of enterprise. Economics. Management. Business. 2016. No 1. P.74-81. (in Ukrainian) Url: http://journals.dut.edu.ua/index.php/emb/article/view/633 (accessed: 24.02.2021)

18. Valitov Sh. M., Khakimov A. Kh. Innovative potential as a framework of innovative strategy for enterprise development. International Conference on Applied Economics, 2-4 July. Procedia Economics and Finance. 2015. Vol.24. P.716-721 (In Russia). Doi:10.1016/S2212-5671(15)00682-6/

19. Rodionova I. V. Methods of evaluation of the innovation potential of industrial enterprises. Economics of Development. 2013. No 4(68). P.96-99. (in Ukrainian).

20. Chorna M., Nord G., Bezghinova L., Melushova I., Diadin A. Company Development Strategy Choice on the Grounds of Innovative Potential Assessment. Academy of Strategic Management Journal. 2019. Vol. 18. Is. $1 . \quad$ Url: https:// www.abacademies.org/articles/company-development-strategy-choice-on-the-grounds-of-innovative-potentialassessment-7868.html (accessed: 21.02.2021).

21. Zamazii O., Stadnyk V. Sokoliuk G., Prylepa N. Optimization Management Model of the Industrial Enterprise Innovation Potential Development on the Basis of a Value-Oriented Approach. Advances in Economics, Business and Management Research. 2019. Vol 95. P.38-43 [Online]. Url: atlantis-press.com/proceedings/smtesm-19/125917617 (accessed: 28.03.2021).

22. Treacy M., Wiersema F. The Discipline of market leaders. New York. Addison-Wesley. 1995. 224 p.

23. Khachatrian V. V. Marketing management providing of entrepreneurial potential as a requirement of modern market. Scientific bulletin of Polissia. 2017. Vol.(9). No2. P.162-167. (in Ukrainian).

24. Tatomyr I. L. Marketing methods of MVOK company professional brand promotion. Economic discourse. 2018. Vol.1. P.24-32. (In Ukrainian). Url: http://188.190.33.55:7980/jspui/bitstream/ 123456789/6784/1/ED\%202018\%281\%29.24-32.pdf (accessed: 22.04.2021)

25. Pererva, P. G., Nagy S., Maslak M. Organization of marketing activities on the intrapreneurship. MIND Journal. 2018.

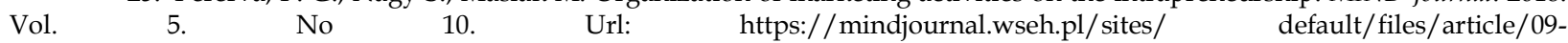
18/organization_of_marketingactivities_on_the_intrapreneurship.pdf (accessed: 22.04.2021)

26. Bianchi M., Di Benedetto A., Franzo S., Frattini F. Selecting early adopters to foster the diffusion of innovations in industrial markets: Evidence from a multiple case study. European Journal of Innovation Management. 2017. Vol. 20. Iss.4. P. 620-644. https://doi.org/10.1108/EJIM-07-2016-0068.

27. Hrihoruk P. M., Khrushch N. A. Integral assessment of the level and dynamics of the innovation potential of the region. Management and marketing of innovations. 2016. Nol. 3. P. 109-129. (in Ukrainian) Url: https://mmi.fem.sumdu.edu.ua/en/journals/2016/3/109-129.

28. Taddeo R., Simboli A., Ioppolo G., Morgante A. Industrial symbiosis, networking and innovation: The potential role of innovation poles. Sustainability. 2017. Vol.9. No 2. P.169. Url: https://www.mdpi.com/2071-1050/9/2/169 (accessed: 21.03.2021).

29. Roig-Tierno N., Ribeiro-Soriano D., Mas-Verdú F. Clustering and innovation: Firm-level strategising and policy. Entrepreneurship \& Regional Development. 2017. Vol. 29. No.7-8. 814-816.Doi.org/10.1080/08985626.2017.13359.58.

30. Dodgson M. Technological collaboration in industry: strategy, policy and internationalization in innovation. Routledge. 2018. Url: routledge.com/Technological- Collaboration-in-Industry-Strategy-Policy-and-Internationalization-in-Innovation/ Dodgson/p/book/9781138578005 (accessed: 21.03.2021)

31. State Statistic Service of Ukraine. Commodity structure of Ukraine's foreign trade. Url: http://www.ukrstat.gov.ua (accessed: 26.04.2021)

32. State Statistic Service of Ukraine. Scientific and innovative activity (2000-2019). Url: http://www.ukrstat.gov.ua/operativ/operativ2019/ni/ind_pp/vi_pp_u.xlsx (accessed: 26.04.2021). 


\title{
МАРКЕТИНГОВА ДОМІНАНТА В МОДЕЛЯХ РОЗВИТКУ ІННОВАЦИИНОГО ПОТЕНЦІАЛУ І РЕАЛІЗАЦІЇ КОНКУРЕНТНИХ БІЗНЕС-СТРАТЕГІЙ ПІДПРИЕМНИЦЬКИХ СТРУКТУР
}

\author{
ВАЛЕНТИНА СТАДНИК ${ }^{1}$, ГАЛИНА КРАСОВСЬКА 2 , ЮЛІЯ ГОЛОВЧУК ${ }^{3}$ \\ ${ }^{1}$ Хмельницький національний університет \\ ${ }^{2}$ Хмельницький національний університет \\ 3 Вінницький торговельно-економічний інститут \\ Київського національного торговельно-економічного університету
}

\begin{abstract}
Метою статті визначено формування релевантних методичних підходів до розвитку інноваційного потенціалу підприємницьких структур для поліпшення їх динамічних характеристик і підвищення здатності до реалізації конкурентних бізнесстратегій. На основі аналізу динаміки і структури експорту продукції машинобудування та результатів інноваційної активності промислових підприємств України висловили припущення про невідповідність їх інноваційного потенціалу завданням конкурентних стратегій. Обгрунтували авторську позицію, що управління розвитком інноваційного потенціалу доиільно розглядати з погляду поліпшення адаптивної і проактивної гнучкості підприємств. Охарактеризували сутність циих складових $i$ їх вплив на вибір підприємством конкурентних бізнес-стратегій. Підкреслили провідну роль і визначили цільові установки маркетингу у забезпеченні обох видів гнучкості. На основі викладеного розробили модель вибору підприємством конкурентної бізнес-стратегії з урахуванням можливості нарощування інноваційного потенціалу через розвиток стратегічного партнерства.

Ключові слова: промисловість, машинобудування, реактивна і проактивна гнучкість, конкурентні переваги, інноваційні стратегї̈, мотиваиійний вплив.
\end{abstract}

